\title{
FACTORS ASSOCIATED WITH PERSISTENCE OF HPV GENITAL INFECTION IN A SMALL COHORT OF ROMANIAN WOMEN
}

\author{
Irina Huică ${ }^{1}$, Iulia Virginia Iancu ${ }^{1}$, Anca Botezatu ${ }^{1}$, Adriana Pleşa ${ }^{1}$, \\ Demetra Socolov ${ }^{2}$, Sergiu Teleman ${ }^{2}$ and Gabriela Anton ${ }^{1}$ \\ ${ }^{1}$ Molecular Virology Department, St. S. Nicolau Institute of Virology, Bucharest, Romania; \\ ${ }^{2}$ Grigore T. Popa University of Medicine and Pharmacy, Iasi, Cuza Voda Obstetrics and Gynecology \\ Clinical Hospital, Iasi, Romania
}

\begin{abstract}
SUMMARY - The aim of the study was to assess the role of behavioral factors in persistence of human papillomavirus (HPV) genital infection. Out of a cohort of 605 women included in a study of HPV infection prevalence, $142 \mathrm{HPV}$ positive women (aged 18-57) were retested after a 12-month interval. None of the patients underwent surgical treatment during that period. Selected patients were asked for a second smear for cytologic analysis and HPV genotyping. A questionnaire that included information regarding reproductive health, sexual activity and smoking status was filled-in. After 12 months, 46 of 142 (32.39\%) women had persistent HPV infection, with genotypes 16 and 18 found in 27 cases. On the other hand, 17 of $142(11.97 \%)$ women had acquired new infections replacing the baseline genotypes. In our study, smoking $(\mathrm{OR}=2.320, \mathrm{p}=0.0330)$ and sexual behavior $(\mathrm{OR}=5.333$, $\mathrm{p}=0.0180$ for more than three sexual partners; $\mathrm{OR}=2.427, \mathrm{p}=0.0238$ for cases where the partner was involved in another sexual relationship) were associated with viral persistence, while long-term contraception did not yield statistically significant results.
\end{abstract}

Key words: Papillomavirus infections; Sexual behavior; Surveys and questionnaires; Romania

\section{Introduction}

Human papillomaviruses (HPV) have epithelial tropism and are found at certain anatomic sites where they can cause specific lesions or cancer. HPV infection is frequently associated with cervical lesions and oral diseases ${ }^{1}$. Genital infection is one of the most common sexually transmitted diseases in both men and women as almost $50 \%$ of sexually active persons tested positive at some point in their lives ${ }^{2,3}$. The risk of acquisition is higher in young subjects, in persons having sex with multiple partners or in case of unprotected intercourse ${ }^{4,5}$. Ho et al. ${ }^{6}$ report that more than half

Correspondence to: Irina Huică, PhD, Molecular Virology Department, St. S. Nicolau Institute of Virology, 285 Mihai Bravu Ave., Bucharest, Romania

E-mail: irina.huica@yahoo.com

Received February 20, 2018, accepted June 12, 2019 of new genital infections resolve within one year, while $90 \%$ resolve within two years. In most cases, HPV infections have a transient character, particularly in young women, but in a small percentage of cases it persists ${ }^{7}$. Persistence of infection with high-risk genotypes (hrHPV) is a necessary (but not sufficient) precondition for development of cervical cancer. In Romania, the incidence of cervical cancer is among highest in Europe $^{8}$ and this type of cancer remains one of the main causes of mortality in women ${ }^{9}$.

Persistent hrHPVs along with other cofactors promoting cell transformation may lead to a severe disease $^{10}$. Among the risk factors that might determine persistent infection are hrHPV genotypes, viral load and lifestyle factors ${ }^{11}$. The ability of some individuals to clear these viral infections appears to correlate with host genetics, HPV genotypes, host immune response characteristics $^{12}$, and other cofactors. Epidemiological 
data have confirmed that these cofactors include long term oral contraceptive use, smoking (through the mutagenic activity of cigarette components), alcohol consumption, parity and presence of other sexually transmitted diseases such as infections with herpes simplex virus type 2, cytomegalovirus, and Chlamydia trachomatis $^{13,14}$. Development of cervical cancer takes years/ decades after initial HPV infection and involves gradual cytologic stages (low- and high-grade intraepithelial lesions) characterized by the presence of hrHPV genotypes. These genotypes were identified in approximately $90 \%$ of cervical neoplasia cases, confirming the etiologic role of this viral infection in cancer development ${ }^{15,16}$. Cytologic screening may reduce the incidence of cervical cancer but it has a limited sensitivity and the quality of results depends on trained cytopathologists. On the other hand, hrHPV DNA testing is considered a more sensitive technique to identify women at risk of developing cervical lesions ${ }^{17}$. Many national cervical screening programs recommend $\mathrm{HPV}$ testing and genotyping in women aged $>30$ (as spontaneous clearance is believed to occur below this age) in order to detect women at risk to develop severe lesions ${ }^{18-20}$.

The aim of this study was to identify factors associated with persistent HPV infection in a small cohort of women with cervical HPV infection.

\section{Subjects and Methods}

Out of a cohort of 605 women included in a study of the prevalence of HPV infection, $142 \mathrm{HPV}$ positive women (aged 18-57) were randomly selected for cytologic and viral retesting after 12 months. Cervical specimens were collected by a gynecologist and conventional cytologic samples were interpreted by trained cytopathologists and reported using the 2001 Bethesda System. For viral tests, exfoliated cervical cells were harvested in Collection and Transport System medium (Copan, Brescia, Italy). None of the patients reported use of vaginal medication in the previous 2 days and no gynecologic investigation for the last year before enrolment. The gynecologist also asked the participants to fill-in a questionnaire in order to collect information on reproductive health, sexual activity and smoking status. All the samples were obtained upon patient agreement and the study protocol was approved by the institutional Ethics Committee.

\section{DNA isolation}

DNA isolation from cervical smears was performed with the High Pure PCR Template Preparation Kit (Roche Molecular Biochemicals, Mannheim, Germany), according to the manufacturer's recommendations. One milliliter of cellular suspension was centrifuged for 10 minutes at $12000 \mathrm{rpm}$ and the pellet was disrupted with a lysis buffer and $\mathrm{K}$ proteinase (10 minutes, $\left.70{ }^{\circ} \mathrm{C}\right)$. The mixture obtained was then treated with isopropanol; DNA was obtained by passing the mixture through purifying columns followed by $8000 \mathrm{~g}$ centrifugation for several times. Isolated DNA samples were subsequently stored at $-20^{\circ} \mathrm{C}$. The concentration and purity of each one were evaluated by a NanoDrop spectrophotometer (NanoDropTechnologies, Montchanin, Delaware, USA).

\section{HPV genotyping}

HPV genotyping was performed using the Linear Array HPV Genotyping Test (Roche Molecular Biochemicals, Mannheim, Germany), according to the manufacturer's instructions. This kit is registered for use in the European Union and allows detection of 37 HPV genotypes, including the high-risk types 16,18 , $31,33,35,39,45,51,52,53,56,58,59,66$ and 68 (http://molecular.roche.com). The method is based on polymerase chain reaction (PCR) DNA amplification followed by hybridization. For PCR amplification, biotinylated primers that amplify near 450 base pairs from L1 viral gene were used. The mastermix contained $10 \mu \mathrm{L}$ DNA, $10 \mathrm{mM}$ Tris $\mathrm{HCl}$ ( $\mathrm{pH}$ 9.0), 50 $\mathrm{mM} \mathrm{KCl}, 2 \mathrm{mM} \mathrm{MgCl}, 200 \mathrm{mM}$ of each dNTP, $1.5 \mathrm{U}$ Ampli Taq Gold and $15 \mathrm{pM}$ of each primer in a final volume of $50 \mu \mathrm{L}$. PCR thermal conditions were as follows: $95^{\circ} \mathrm{C}$ for 9 minutes, 40 cycles of 30 seconds at 95 ${ }^{\circ} \mathrm{C}$ denaturation, annealing 45 seconds at $52{ }^{\circ} \mathrm{C}$ and extension 45 seconds at $72^{\circ} \mathrm{C}$, followed by final extension of 5 minutes at $72{ }^{\circ} \mathrm{C}$. The resulting PCR products were hybridized to molecular probes immobilized on a strip. An additional primer pair targets the human $\beta$-globin gene to provide control for cell adequacy, extraction and amplification.

\section{Statistical analysis}

The GraphPad Prism ver. 5.0 software was used on statistical analysis. Fisher exact test was performed as a statistical tool; relative risk $(\mathrm{RR})$ and odds ratio $(\mathrm{OR})$ 
were computed with $95 \%$ confidence interval (95\% CI). The level of statistical significance was set at $\mathrm{p}<0.05$.

\section{Results and Discussion}

Viral testing of selected patients at baseline revealed the presence of hrHPV genotypes as single infection in $53(37.32 \%)$ and as co-infection in 50 (35.21\%) cases. Among high-risk genotypes, HPV 16 was prevalent, being identified (both in single and coinfections) in 37 (26.06\%) cases, followed by HPV 18 found in 25 (17.61\%) and HPV 31 in 16 (11.27\%) patients.

Upon dividing study patients into three age subgroups ( $<29,30-39$ and $>40$ years), the highest percentage of hrHPV single infections and hrHPV coinfections was recorded in women of the 30-39 and $<30$ age groups, respectively (Table 1 ).

At baseline, 74 patients were negative for intraepithelial lesion or malignancy (NILM), 17 were classified as atypical squamous cells of undetermined significance (ASCUS) and 51 as low-grade squamous intraepithelial lesion (LSIL).

After 12 months, all 142 women included in the study were retested both for HPV DNA and genotype, and for cytologic status. Persistent infection is confirmed by the presence of the same HPV genotype on two or more consecutive tests ${ }^{21}$. Follow-up genotyping for hrHPVs could be more accurate in predicting the risk of viral infection. In patients with persistent infection, Schiffman et al. noted the risk of acquiring a malignant phenotype to be very high for 5\% of HPV infections that persist for several years ${ }^{22}$.

In our study group, at follow-up we found 63 of 142 women $(44.37 \%)$ to be still HPV positive, while 79 (55.63\%) tested negative. Among positive samples at follow-up, the same genotypes were detected in 46 (32.39\%) cases, whereas the rest of 17 positive cases infected with different HPV genotypes were not included in statistical analysis of the factors associated with persistence. According to HPV status at followup, patients were divided into three groups, as follows: group A, patients having cleared the infection (79 cases); group B, patients testing positive for the same genotype(s) - persistent infection (46 cases); and group C, patients testing positive for genotypes other than baseline (17 cases) (Table 2).
At follow-up, HPV 16 was found in 16, HPV 18 in 11 and HPV 31 in 8 cases. The increased persistence of HPV 16 may have also been due to the viral variants found in our country ${ }^{23}$. It should be noted that genotypes 18 and 31 were also found to have a rather high prevalence both at baseline and at follow-up. These data are consistent with other studies of the prevalence of HPV in Romania ${ }^{8,9}$. Overall, 60 cases of hrHPV were recorded both in persistent single and co-infections.

During the study period, cytologic profile improved in group $\mathrm{A}$, worsened in group $\mathrm{B}$ and remained almost unchanged in group $\mathrm{C}$. These data are presented in Table 3.

At baseline, cytologic diagnosis was NILM in 74 patients and ASCUS or worse in 68 patients. At follow up, we found 70 patients with NILM and $72 \mathrm{pa-}$ tients with ASCUS or worse, but the distribution of NILM/ASCUS or worse, as well as the evolution of cytologic status was very different between the patients having cleared the infection and those with persistent infection. To be more specific, in group A the number of patients with cytologic diagnosis of NILM increased from 47 at baseline to 51 at follow up, whereas the number of those having ASCUS or LSIL cytology decreased from 32 to 28; in group B, only 10 out of 19 cases retested NILM cytology at follow up, whereas the number of patients with ASCUS and LSIL increased from 27 to 36 (Fig. 1). These data show that in our patients, clearance of infection was associated with improvement, and persistence of infection with worsening of the cytologic status.

To correlate viral persistence with cofactors (smoking, marital status, number of partners, pregnancies or long-term oral contraceptive use), Fisher exact test with 95\% CI was performed; HPV negative patients at follow up $(\mathrm{n}=79)$ were considered as a reference versus those presenting persistent infection $(n=46)$. Since only $14 \%$ of the study subjects reported condom use, this parameter was not included in the statistics. The contribution of each genotype to viral persistence was difficult to estimate because of the small number of cases (no statistical significance was obtained). Statistical analysis results are presented in Table 4.

Smoking, increased number of sexual partners or partners having sex with other partners better correlated with infection persistence. The most statistically significant results were obtained for patients who de- 
Table 1. Distribution of viral infection types according to patient age

\begin{tabular}{|l|l|l|l|l|}
\hline Age $(\mathrm{yrs})$ & Cases, $\mathrm{n}$ & hrHPV single infection & hrHPV co-infection & lrHPV infection \\
\hline$<30$ & 53 & $16(11.27 \%)$ & $19(13.38 \%)$ & $18(12.67 \%)$ \\
\hline $30-39$ & 59 & $25(17.61 \%)$ & $15(10.56 \%)$ & $19(13.38 \%)$ \\
\hline$>40$ & 30 & $12(8.45 \%)$ & $16(11.27 \%)$ & $2(1.41 \%)$ \\
\hline
\end{tabular}

hrHPV = high-risk human papillomavirus; lrHPV = low-risk human papillomavirus

Table 2. Prevalence of HPV genotypes in single and co-infections in study groups

\begin{tabular}{|c|c|c|c|c|c|}
\hline \multirow{2}{*}{\multicolumn{2}{|c|}{ HPV genotype }} & \multirow{3}{*}{\begin{tabular}{|l}
$\begin{array}{l}\text { Baseline } \\
\text { cases } \\
(\mathrm{N})\end{array}$ \\
37
\end{tabular}} & \multicolumn{3}{|c|}{ Follow up } \\
\hline & & & \multirow{2}{*}{\begin{tabular}{|l}
$\begin{array}{l}\text { Group A } \\
\text { (clearance), } \\
n\end{array}$ \\
16 \\
\end{tabular}} & \multirow{2}{*}{\begin{tabular}{|l|}
$\begin{array}{l}\text { Group B } \\
\text { (persistence), } \\
n\end{array}$ \\
16
\end{tabular}} & \multirow{2}{*}{\begin{tabular}{|l|}
$\begin{array}{l}\text { Group C } \\
\text { (other genotype), } \\
\mathrm{n}\end{array}$ \\
5 \\
\end{tabular}} \\
\hline \multirow{15}{*}{ High risk } & 16 & & & & \\
\hline & 18 & 25 & 10 & 11 & 4 \\
\hline & 31 & 16 & 6 & 8 & 2 \\
\hline & 33 & 6 & 2 & 3 & 1 \\
\hline & 35 & 1 & 1 & 0 & 0 \\
\hline & 39 & 2 & 0 & 1 & 1 \\
\hline & 45 & 5 & 3 & 1 & 1 \\
\hline & 51 & 10 & 6 & 3 & 1 \\
\hline & 52 & 2 & 1 & 1 & 0 \\
\hline & 53 & 10 & 8 & 2 & 0 \\
\hline & 56 & 1 & 1 & 0 & 0 \\
\hline & 58 & 7 & 2 & 3 & 2 \\
\hline & 59 & 3 & 1 & 2 & 0 \\
\hline & 66 & 15 & 6 & 7 & 2 \\
\hline & 68 & 13 & 8 & 2 & 3 \\
\hline \multirow{8}{*}{ Low risk } & 6 & 9 & 5 & 3 & 1 \\
\hline & 11 & 8 & 7 & 0 & 1 \\
\hline & 40 & 3 & 3 & 0 & 0 \\
\hline & 54 & 6 & 4 & 1 & 1 \\
\hline & 61 & 3 & 2 & 1 & 0 \\
\hline & 62 & 5 & 3 & 2 & 0 \\
\hline & 70 & 4 & 4 & 0 & 0 \\
\hline & 71 & 1 & 0 & 1 & 0 \\
\hline
\end{tabular}

$\mathrm{HPV}=$ human papillomavirus; $\mathrm{N}$ = number of patients; $\mathrm{n}=$ number of specific HPV genotype identified in patient subgroups

Table 3. Cytologic profile of study patients at baseline and follow up

\begin{tabular}{|l|l|l|l|l|l|l|}
\hline Case group & \multicolumn{3}{|c|}{ Baseline } & \multicolumn{3}{c|}{ Follow up } \\
\hline (n) & NILM & ASCUS & LSIL & NILM & ASCUS & LSIL \\
\hline Group A (79) & 47 & 8 & 24 & 51 & 16 & 12 \\
\hline Group B (46) & 19 & 6 & 21 & 10 & 18 & 18 \\
\hline Group C (17) & 8 & 3 & 6 & 9 & 2 & 6 \\
\hline Total & 74 & 17 & 51 & 70 & 36 & 36 \\
\hline
\end{tabular}

NILM = negative for intraepithelial lesion or malignancy; LSIL = low-grade squamous intraepithelial lesion; ASCUS = atypical squamous cells of undetermined significance 
clared more than three sexual partners $(\mathrm{p}=0.0180$, $\mathrm{OR}=5.333)$ and for cases where the partner was involved in another sexual relationship $(\mathrm{p}=0.0238$, $\mathrm{OR}=2.427)$. Good correlations recorded for smoking $(\mathrm{p}=0.0330, \mathrm{OR}=2.320)$ may be explained by the effect of this habit on the immune system ${ }^{24}$. It is also impor-

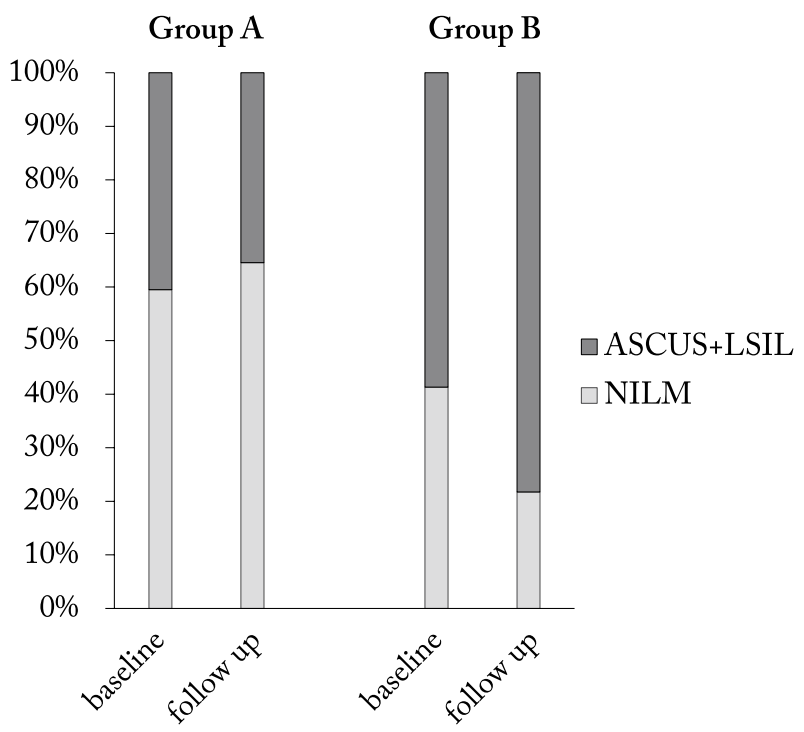

Fig. 1. Distribution of patients with NILM and ASCUS or worse cytology in clearance and persistence groups.

LSIL = low-grade squamous intraepithelial lesion; ASCUS = atypical squamous cells of undetermined significance; NILM = negative for intraepithelial lesion or malignancy tant to stress that in our country, the incidence of smoking is about $23 \%$ for female population, according to the latest estimates ${ }^{9}$. The results of our study indicated that in our case group, smoking and sexual behavior were associated with viral persistence. Longterm oral contraception did not yield a statistically significant result $(p>0.05)$, while having more than two pregnancies was not significantly correlated with either persistence or clearance $(\mathrm{p}=0.2647)$.

Social background could influence the acquisition of $\mathrm{HPV}^{25}$, but in our study that included a small number of cases, no statistically significant correlations were observed between HPV persistence and level of education. Most of the participants were from urban areas (128 of 142 of cases), 85/142 reported high education, 26/142 had completed high school, and only a small number (14/142) had completed elementary school.

Persistent HPV infection is a necessary but not sufficient cause for cervical cancer development ${ }^{2,26}$, and fortunately, most of these infections have a transient nature ${ }^{16}$. As observed in large screening studies, longterm hrHPV infections that pass through different pre-malignant stages are more likely to lead to can$\operatorname{cer}^{21}$.

Detecting HPV and discriminating high- and lowrisk genotypes may not be enough, on the one hand because of the great number of transient infections,

Table 4. Correlation between human papillomavirus (HPV) persistence and cofactors

\begin{tabular}{|c|c|c|c|c|c|c|c|c|}
\hline & & Clearance & Persistence & $\mathrm{RR}$ & $95 \% \mathrm{CI}$ & OR & $95 \% \mathrm{CI}$ & $p$ \\
\hline \multirow{2}{*}{ Smoking } & No & 58 & 25 & \multirow{2}{*}{1.351} & \multirow{2}{*}{1.004 to 1.817} & \multirow{2}{*}{2.320} & \multirow{2}{*}{1.079 to 4.988} & \multirow{2}{*}{$0.0330^{*}$} \\
\hline & Yes & 21 & 21 & & & & & \\
\hline \multirow{2}{*}{$\begin{array}{l}\text { Age at first sexual } \\
\text { intercourse }\end{array}$} & $>20$ & 23 & 19 & \multirow{2}{*}{0.7049} & \multirow{2}{*}{0.4331 to 1.147} & \multirow{2}{*}{0.5836} & \multirow{2}{*}{0.2725 to 1.250} & \multirow{2}{*}{0.1752} \\
\hline & $\leq 20$ & 56 & 27 & & & & & \\
\hline \multirow{2}{*}{ Number of partners } & $<4$ & 76 & 38 & \multirow{2}{*}{1.165} & \multirow{2}{*}{1.013 to 1.339} & \multirow{2}{*}{5.333} & \multirow{2}{*}{1.337 to 21.27} & \multirow{2}{*}{$0.0180^{*}$} \\
\hline & $\geq 4$ & 3 & 8 & & & & & \\
\hline \multirow{2}{*}{$\begin{array}{l}\text { Partners having } \\
\text { other partners }\end{array}$} & No & 53 & 21 & \multirow{2}{*}{1.470} & \multirow{2}{*}{1.034 to 2.088} & \multirow{2}{*}{2.427} & \multirow{2}{*}{1.150 to 5.119} & \multirow{2}{*}{$0.0238^{*}$} \\
\hline & Yes & 26 & 25 & & & & & \\
\hline \multirow{2}{*}{ Married } & Yes & 62 & 29 & \multirow{2}{*}{1.245} & \multirow{2}{*}{0.9699 to 1.598} & \multirow{2}{*}{2.138} & \multirow{2}{*}{0.9566 to 4.778} & \multirow{2}{*}{0.0945} \\
\hline & No & 17 & 17 & & & & & \\
\hline \multirow{2}{*}{ Pregnancies } & $<3$ & 41 & 29 & \multirow{2}{*}{0.8232} & \multirow{2}{*}{0.6058 to 1.119} & \multirow{2}{*}{0.6325} & \multirow{2}{*}{0.6144 to 2.430} & \multirow{2}{*}{0.2647} \\
\hline & $\geq 3$ & 38 & 17 & & & & & \\
\hline \multirow{2}{*}{$\begin{array}{l}\text { Oral contraceptive } \\
\text { use }\end{array}$} & Yes & 34 & 12 & 1650 & 09530 to 2856 & 2141 & 0.9669 to 4740 & 00830 \\
\hline & No & 45 & 34 & 1.050 & $0.7350+0.050$ & 2.141 & 0.300304 .670 & 0.0030 \\
\hline
\end{tabular}

*Statistically significant at $\mathrm{p}<0.05 ; \mathrm{RR}=$ relative risk; $95 \% \mathrm{CI}=95 \%$ confidence interval; $\mathrm{OR}=$ odds ratio 
and on the other hand because persistent hrHPV infection correlates with malignancy. Persistent infections can only be detected by genotyping, when the same genotype is found at retesting. Taking these facts in consideration, genotyping-based screening combined with Papanicolaou test has better chances to find patients with persistent infections associated with modified cytology, resulting in better clinical management ${ }^{14-17}$. Still, due to a large number of transient infections found in women aged $<30$, viral screening is efficient for patients over this age, as demonstrated in our study.

Due to the small number of cases, we were unable to evaluate the contribution of different genotypes to persistence of infection, but HPV 16 was found most frequently on retesting in our study group (16 out of 46 cases of persistent infection).

\section{Acknowledgments}

This research was funded by the national partnership research project PNII 49030. The study was also supported by Project 433/ID 929/SMIS code 14049 .

\section{References}

1. Zendeli-Bedjeti L, Popovska M, Atanasovska-Stojanovska A, Duvlis S. Human papillomavirus as a potential risk factor for oral premalignant lesions. Acta Clin Croat. 2017 Sep;56(3): 369-74, https://doi.org/10.20471/acc.2017.56.03.02

2. Muñoz N, Bosch FX, de Sanjosé S, Herrero R, Castellsagué X, et al. International Agency for Research on Cancer Multicenter Cervical Cancer Study Group. Epidemiologic classification of human papillomavirus types associated with cervical cancer. N Eng1 J Med. 2003 Feb 6;348(6):518-27, https://doi.org/ 10.1056/NEJMoa021641

3. Schiffman M, Castle PE. Human papillomavirus: epidemiology and public health. Arch Pathol Lab Med. 2003 Aug;127(8):930-4, https://doi.org/10.1043/1543-2165(2003) 127<930:HPEAPH>2.0.CO;2

4. Syrjanen S, Shabalova I, Petrovichev N, Kozachenko V, Zakharova T, Pajanidi J, et al. Factors predicting persistence of highrisk human papillomavirus (HPV) infections in women prospectively followed-up in three New Independent States (NIS) of the former Soviet Union. Eur J Gynaecol Oncol. 2005; 26(5):491-8, https://doi.org/10.1128/JCM.42.2.505-511.2004

5. Steben M, Duarte-Franco E. Human papillomavirus infection: epidemiology and pathophysiology. Gynecol Oncol. 2007 Nov;107(2 Suppl 1):S2-5, https://doi.org/10.1016/j.ygyno. 2007.07.067

6. Ho GY, Bierman R, Beardsley L, Chang CJ, Burk RD. Natural history of cervicovaginal papillomavirus infection in young women. N Engl J Med. 1998 Feb 12;338(7):423-8, https://doi. org/10.1056/NEJM199802123380703

7. Venturoli S, Ambretti S, Cricca M, Leo E, Costa S, Musiani M, et al. Correlation of high-risk human papillomavirus genotypes persistence and risk of residual or recurrent cervical disease after surgical treatment.J Med Virol. 2008 Aug;80(8):1434-40, https://doi.org/10.1002/jmv.21198

8. Anton G, Peltecu G, Socolov D, Cornitescu F, Bleotu C, Sgarbura Z, et al. Type-specific human papillomavirus detection in cervical smears in Romania. APMIS. 2011 Jan;119(1):1-9, https://doi.org/10.1111/j.1600-0463.2010.02641.x

9. Bruni L, Barrionuevo-Rosas L, Albero G, Serrano B, Mena M, Gómez D, Muñoz J, Bosch FX, de Sanjosé S. Human papillomavirus and related diseases in Romania. Summary Report 2017 July 27. [Oct 2017]. ICO Information Centre on HPV and Cancer (HPV Information Centre).

10. Burd EB. Human papillomavirus and cervical cancer. Clin Microbiol Rev. 2003 Jan;16(1):1-17, https://doi.org/10.1128/ CMR.16.1.1-17.2003

11. Franco EL, Duarte-Franco E, Ferenczy A. Cervical cancer: epidemiology, prevention and the role of human papillomavirus infection. CMAJ. 2001 Apr 3;164(7):1017-25.

12. Stensen S, Kjaer SK, Jensen SM, Frederiksen K, Junge J, Iftner T, Munk C. Factors associated with type-specific persistence of high-risk human papillomavirus infection: a population-based study. Int J Cancer. 2016 Jan 15;138(2):361-8, https://doi. org/10.1002/ijc.29719

13. Smith JS, Herrero R, Bosetti C, Munoz N, Bosch FX, ElufNeto J. Herpes simplex virus-2 as a human papillomavirus cofactor in the etiology of invasive cervical cancer. J Natl Cancer Inst. 2002 Nov 6;94(21):1604-13, https://doi.org/10.1093/ jnci/94.21.1604

14. Castellsagué X, Muñoz N. Chapter 3: Cofactors in human papillomavirus carcinogenesis - role of parity, oral contraceptives, and tobacco smoking. J Natl Cancer Inst Monogr. 2003; 31:20-8.

15. Snijders PJ, Steenbergen RD, Heideman DA, Meijer CJ. HPV-mediated cervical carcinogenesis: concepts and clinical implications. J Pathol. 2006 Jan;208(2):152-64, https://doi. org/10.1002/path.1866

16. Bosch FX, Burchell AN, Schiffman M, Giuliano AR, de Sanjose S, Bruni L, et al. Epidemiology and natural history of human papillomavirus infections and type-specific implications in cervical neoplasia. Vaccine. 2008 Aug 19;26(10):K1-16, https://doi.org/10.1016/j.vaccine.2008.05.064

17. Naucler P, Ryd W, Törnberg S, Strand A, Wadell G, Elfgren K, et al. Efficacy of HPV DNA testing with cytology triage and/ or repeat HPV DNA testing in primary cervical cancer screening. J Natl Cancer Inst. 2009 Jan 21;101(2):88-99, https://doi. org/10.1093/jnci/djn444

18. Denis F, Hanz S, Alain S. Clearance, persistence and recurrence of HPV infection. Gynecol Obstet Fertil. 2008 Apr;36(4): 430-40, https://doi.org/10.1016/j.gyobfe.2008.02.008 
19. Costa S, De Simone P, Venturoli S, Cricca M, Zerbini ML, Musiani M. Factors predicting human papillomavirus clearance in cervical intraepithelial neoplasia lesions treated by conization. Gynecol Oncol. 2003 Aug;90(2):358-65, https://doi. org/10.1016/S0090-8258(03)00268-3

20. Castle PE. The potential utility of HPV genotyping in screening and clinical management. J Natl Compr Canc Netw. 2008 Jan;6(1):83-95, https://doi.org/10.6004/jnccn.2008.0008

21. Woodman CBJ, Collins SI, Young LS. The natural history of cervical HPV infection: persistent HPV Infection. Nat Rev Cancer. 2007 Jan;7(1):11-22, https://doi.org/10.1038/nrc2050

22. Schiffman M, Wentzensen N, Wacholder S, Kinney W, Gage JC, Castle PE. Human papillomavirus testing in the prevention of cervical cancer. J Natl Cancer Inst. 2011 Mar 2;103(5): 368-83, https://doi.org/10.1093/jnci/djq562

23. Plesa A, Anton G, Iancu IV, Diaconu CC, Huica I, Stanescu $\mathrm{AD}$, et al. Molecular variants of human papillomavirus $16 \mathrm{E} 2$,
E4, E5, E6 and E7 genes associated with cervical neoplasia in Romanian patients. Arch Virol. 2014 Dec;159(12):3305-20, https://doi.org/10.1007/s00705-014-2199-8

24. Sopori M. Effects of cigarette smoke on the immune system. Nat Rev Immunol. 2002 May;2(5):372-7, https://doi.org/ $10.1038 /$ nri803

25. Cernescu E, Ruta S, Botezatu A, Anton G, Cernescu C. Impact of education level and life-style related factors on high-risk human papillomaviruses infections. Rom Biotechnol Lett. 2014; 19(2):9272-9.

26. Adam E, Berkova Z, Daxnerova Z, Icenogle J, Reeves WC, Kaufman RH. Papillomavirus detection: demographic and behavioral characteristics influencing the identification of cervical disease. Am J Obstet Gynecol. 2000 Feb;182(2):257-64, https://doi.org/10.1016/s0002-9378(00)70208-0

Sažetak

\title{
ČIMBENICI UDRUŽENI S USTRAJNOM GENITALNOM INFEKCIJOM HUMANIM PAPILOMAVIRUSOM U MANJOJ SKUPINI RUMUNJSKIH ŽENA
}

\author{
I. Huică, I.V. Iancu, A. Botezatu, A. Pleşa, D. Socolov, S. Teleman i G. Anton
}

Cilj ovoga istraživanja bio je procijeniti ulogu čimbenika ponašanja na ustrajnost genitalne infekcije humanim papilomavirusom (HPV). Od 605 žena uključenih u ispitivanje učestalosti infekcije HPV-om 142 žene pozitivne na HPV (u dobi od 18 do 57 godina) ponovno su testirane nakon 12 mjeseci. Tijekom tog razdoblja nijedna od tih bolesnica nije bila podvrgnuta kirurškom liječenju. Od odabranih bolesnica zatražen je drugi obrisak za citološku analizu i genotipiziranje HPV-a. Ispunjen je upitnik s podacima o reprodukcijskom zdravlju, seksualnim aktivnostima i pušenju. Nakon 12 mjeseci 46/142 $(32,39 \%)$ žena imalo je ustrajnu infekciju HPV-om; u 27 slučajeva utvrđeni su genotipovi 16 i 18. S druge strane, 17/142 $(11,97 \%)$ žena imalo je novo stečene infekcije koje su zamijenile prvobitne genotipove. U našem istraživanju je pušenje $(\mathrm{OR}=2,320, \mathrm{p}=0,0330)$ i spolno ponašanje $(\mathrm{OR}=5,333, \mathrm{p}=0,0180$ za više od tri seksualna partnera; $\mathrm{OR}=2,427, \mathrm{p}=0,0238 \mathrm{u}$ slučajevima kad je partner imao i drugi seksualni odnos) bilo udruženo s ustrajnošću virusa, dok dugotrajna kontracepcija nije pokazala statistički značajne rezultate.

Ključne riječi: Papilomavirus, infekcije; Seksualno ponašanje; Ankete i upitnici; Rumunjska 